\title{
Widows' Socio-Demographic Characteristics and the Observance of Widowhood Rites among the Aworis of Ogun State
}

\author{
Tayo 0. George \\ Covenant University, Nigeria \\ Email: tayo.george@covenantuniversity.edu.ng \\ Dare Ojo Omonijo \\ Covenant University, Nigeria \\ Email:omonijoojo@yahoo.com \\ Onyekwere O. C. Uche \\ Nnamdi Azikiwe University, Awka, Nigeria \\ Email: ooc.uche@unizik.edu.ng \\ Michael Chibuzor, Anyaegbunam \\ Nnamdi Azikiwe University; Nigeria \\ Email: mykelivingstone777@yahoo.com \\ Albert Oguche Shaibu \\ Kogi State College of Education, Ankpe, Nigeria \\ Email: fralbertshaibu@gmail.com
}

Doi:10.5901/mjss.2016.v7n4p317

\section{Abstract}

This study examined the socio-demographic characteristics of widows in Awori two urban and two rural communities of Awori land in Ogun State, Nigeria and the observance of widowhood rites. It utilized a survey questionnaire containing open and closed ended questions to elicit information from 912 respondents. The linear regression was used in testing the hypothesis formulated for the study, in addition to cross-tabulations and simple percentages. The critical variables in the hypothesis are ten (10) indices which helped to measure the socio-demographic attributes of the widows sampled. The indices are: age, education, income, occupation, number of children, sex of children, religion, type of marriage, form of marriage and place of residence). The purpose was to determine which of these indicators had the most effect on the widowhood practices outcomes. The results revealed no relationships between the dependent and independent variables in the first model except for education and type of marriage which were found to be significantly related to widowhood rites. In the second model, widows' education and occupation were both positively related to property inheritance and statistically significant. Finally, the study presented conclusion and recommendations on the basis of the findings.

Keywords: Widows, Socio-demographic Characteristics, Widowhood rites Awori.

\section{Introduction}

Several articles have featured prominently on women's position globally (Lee; Demaris; Bavin and Sullivan, 2001; Simon, 2002; Li, Liang and Toler, 2005; Cohen, 2006; Trivedi, Himanshu and Mohan, 2009). While some of these scholars argue that women are well treated in developed nations, others contend that women are poorly treated in underdeveloped nations. Hence, in spite of the positive effect of globalization in compressing the world to a small village with the aim of improving the standard of living of people, it is evident in the literature that the condition of women has remained deplorable in Third World countries (Cohen, 2006). It is against this background that Ezejiofor (2011) argues, with particular reference to Nigeria that in spite of impacts of feminists, women's position has remained far below that of men. 
Previous studies have attributed the root of the painful subjugation of women in underdeveloped nations mainly to cultural factors. Although, women's subjugation is a global issue of concern, the problem is better addressed in developed nations than underdeveloped countries where people keep on holding to obnoxious customs and traditions that undermine women's fundamental human rights (Kristof and Wudunnaug, 2009). Hence, women have fared well in countries dominated by Western culture than countries dominated by non-Western culture (Cohen, 2006). This could largely be attributed to western education that has greatly assisted in elevating women in developed nations than their counterparts in Third World nations, where the level of illiteracy is alarming. As illustrated in previous studies, illiteracy is strongly connected with ignorance, poor and subjective reasoning as well as prejudice among people in Third World countries (Omonijo and Nnedum, 2012). These factors have caused many people to develop negative perspectives about women. Consequently, they are perceived as the weaker sex, unintelligent and as a sexual object whose place in life should be restricted to the kitchen.

The case of women in sub-Saharan Africa (SSS) is very pathetic. Blind obedience to the dictates of tradition, even with western civilization, has continued to worsen the position of women. For instance, the attention given to the observance of widowhood rites could be regarded as one of the ways of subjugating women. Although, widowhood practices have been in existence for a long time in the society and they have become cogent aspects of cultural, religious and social life, however, contemporary societies must eradicate the obnoxious aspects of these practices in order to assist women.

Widowhood could be perceived as a social problem that has no regard for sex. However, it is obvious that women are more affected than men as far as it concerned. This can be attributed to the following reasons: first, women's life expectancy is higher than that of men folk; second, even though not mandatory, it is a common practice for men to marry ladies much younger than themselves.

Given the above, women are more prone to widowhood than men. In Nigeria, widowhood is a common phenomenon and it has been attributed to the high and increasing mortality rate (Oyekanmi, 2007). The fact that females have higher average life expectancy than males coupled with the practice whereby men marry women younger than themselves likely result in more widows than widowers in the society.

Widowhood is also perceived by Holden and Kim (2002) as a situation in which a woman or a man loses his or her legally married spouse to death. This, more often than not, causes a woman in some cultures to lose income and inheritance rights, unless a will is prepared by the spouse when alive. In developed societies, marriage defines will and it is fully backed up by an effective legal practice. The position of a wife and inheritance is, therefore, well defined to guarantee her financial security and that of her children. Such is relatively lacking in West Africa and it gives room for an extended family incursion into the property of a deceased man to the detriment of his spouse and children.

Based on UN (2000) data, widows constitute the majority of all women worldwide, but this information depends on data available in each country. While the data could be accurate in developed nations, certainly, it is very difficult to ascertain such data in Third World countries due to poor level of research.

Until the 1990s, not much research had been done on widows and their plights in any discourse in Nigeria. Yet, this is one specific sub-group that should be targeted for intervention, considering the incidence of social and psychological depression among them. Also, the socio-economic set back that the crises inflict on widows cannot be easily ignored. It could be connected with their sudden change of status. It is against this backdrop that this paper was conceived. This study intends to: (i) investigate the socio-demographic characteristics of widows: (age, education, income, occupation, sex and number of children, religion, type and form of marriage, place of residence) in the study area, (ii) examine the relationship between widows' socio-demographic characteristics and observance of widowhood rites, (ii) bridge a gap in literature in the area of widows' socio-demographic characteristics and conformity to widowhood practices, (iii) examine the common widowhood practices in the study area

This article proceeds in the following order: Introduction, literature review and methodology.

\subsection{Operational Definition of Terms}

1. Widows. As used in this study widows refer to married women regardless of socio-economic status (young or old, literate or non-literate, low or high-income earner, etc) whose husbands have died and have not remarried. Sometimes, women who had children for a man outside wedlock are called widows too.

2. Widowhood rites. These are socio-cultural norms and traditions observed by widows in honour of their dead husbands. 


\subsection{Perspectives of Scholars on Widowhood}

Nwoga (1989) sees widowhood practice as a set of actions expected to be carried out by the widow after the death of her husband death, usually for a certain period. Similarly, Nwaogugu (1989) considers widowhood practice as one manifestation of the ritual cleansing which tradition prescribes for all members of the community following any death or other influences regarded as corrupting. He adds that in lgbo land, soldiers returning from war were expected to undergo a ritual cleansing of the hands before resuming normal relations with other members of their communities. In the same manner, the widow, being considered as corrupted and defiled by her close contact with death through her husband, would be subjected to a period of regimented seclusion. Nwaogugu (1989) observes thatthis period would enable her undergo the appropriate cleansing ritual. Ahonsi (2001) notes that widowhood practices differ from one location to another even within the same domain. However, what remains a general fact is that in addition to her loss and its attendant consequences, the widow is subjected to the whims of a culture she has no control over and to which she must submit herself.

In spite of the prevalence of widowhood practices across most societies in Nigeria, there exists a dearth of literature on this vital aspect of the people's culture. For instance, Korieh (1996) noted inadequate data in this respect. In a similar vein, attempt has not been made to explain the practice in sociological and cosmological terms (Afigbo, 1986). The dearth of scholarly works that would have questioned this aspect of women's life shows evidence of her 'silence and invisibility'.

\subsection{Independent Variables (Socio-demographic Characteristics of Widows)}

The independent variables are categorized as the socio-demographic characteristics of the widows sampled in the study. Ten (10) indicators were used to delineate this category of the Independent Variables. They are: age, education, income, occupation, number of children, religion, type of marriage, form of marriage and place of residence.

\subsubsection{Age}

Age is one of the crucial socio-demographic characteristics relating to this study. It implies the actual age of the widow as at the last birthday. Identifying the minimum and maximum age at widowhood, as well as ascertaining the mean age of widows, is relevant to explaining the socio-demographic attributes of the widows. Age of widow and level of observance of widowhood rites will assist to shed more light on whether the younger widows conform or observe stipulated widowhood rites more than the older widows or vice-versa.

\subsubsection{Education}

Education is another important socio-demographic characteristic of widows considered in this study. Education is very important in determining people success (Omonijo, Uche, Rotimi and Nwadialor (2014) in life. It is a strong variable in determining the quality of life and it can be used to measure the extent of individual investment in human capital. A basic assumption in this study is that the level of education of the respective widows may influence individual ability to accept and/or reject obnoxious widowhood practices.

\subsubsection{Income}

According to Cambridge Dictionaries Online (2015) income is the 'money that is earned from doing work or received from investments'. With reference to this article, income is described as the total earnings of the widow per month. The income is derived from what the widow earns or receives as proceeds from individual occupation / business, which could include wages or salaries or profit from other businesses. Important measure for this study is the average monthly income per widow, which presents a good indicator of the quality of life of the respective widows in the target area.

\subsubsection{Occupation}

Occupation is an assignment that one does to earn a living The Free Dictionary, (2015). Sociologically, the importance of occupation cannot be easily ignored among mankind. It provides means of livelihood for humanity and prevents people from extinction from one generation to another. Occupation is a crucial index which can be used to measure peoples 
socio-economic status. A widow who is engaged in independent income generating activity with no recourse to lineagemode of production (that is, independent of lineage-based resources such as land; housing; or other extended family owned resources) may find it easy to challenge exploitative and obnoxious widowhood rites.

\subsubsection{Number of Children}

This is the total number of living children a widow has as at the time of observing widowhood rites. Children are very important in most culture. In Africa for instance, the major aim of men getting married to women is to bear children for the continuity of their linage and that of the society. They are more or less perceived as baby making machines (Azogu, 1991). In other words, it is their child bearing role that makes women more important to their husbands. On this note Bier (1968) argues that barren women are often pitied and ridiculed in the society and to most of them life is meaningless. This is because the number of children a widow has could determine her acceptance of widowhood. A barren woman may consider it unnecessary to engage in the rite because she may think that her place in the man's house is empty.

\subsubsection{Sex of Children}

The sex of the widow's children is the biological classification of her children into either male or female and it has significant traditional implications on the position of women after the death of her husband. In most culture, a woman who gives birth to female children only is denied access to her husband's property. The economic and social implications of this on widows could be grievous for widows and their children.

\subsubsection{Religion}

It is common knowledge that scholars perceive the concept of religion differently. Doglas, (1981) believes that while Sociologists stress the social dimension of religious ideas and therefore describe term as the collective expression of human values, the anthropologists describe religious beliefs and practices as they find them in living communities. This scholar also argues that 'the historians describe religion in terms of events resulting front beliefs. Similarly, Walter (1983) views religion as an organized system of beliefs, ceremonies, practices, and worships that center on one Supreme God, or the Deity.

Given the above, it is the belief system of the widow which informs her object of worship and reverence. According to George \& Amusan (2012), the various ethnic groups in Nigeria have their peculiar religions and modes of worship. Similarly, religion varies from one widow to another. While some widows are adherent of the traditional religion others belong to Christian, Muslim, Hindus etc faiths. Thus, religious affiliation of widows could define the extent of their observance of widowhood rite.

\subsubsection{Type of marriage}

It is evident in the literature that Marriages are of different types across the world (Sociology Guide, 2015). This study assumes that the type of marriage consummated (Christian, Islam or Traditional) reflects unique ideology and practice which is likely influence the mode of widowhood rites. The study therefore expects variations in the experiences of the selected widows based on the types of marriage arrangements. Each marriage type dictates specific ideology and widowhood rites. The study also explores the extent to which each marriage type dictates widowhood rites observed by the widow.

\subsubsection{Form of marriage}

This implies whether the widow's husband practiced monogamy (marriage of one man to one woman) or polygyny (marriage of one man to more than one wife). The form of marriage may inform the rapport and the extent of cordial relationship that exist between the widow and her husband even while alive or in death vis-à-vis the widows' level of conformity to widowhood rites as a mark of love, honour and respect for the deceased husband.

\subsubsection{Place of Residence}

In literature, a place of residence has been considered as a strong factor in predicting social life issues among mankind 
(Goodridge, Lawson, Rennie and Marciniuk, 2010; Pallares, 2011; Lahana, Pappa and Niakas, 2011). However, widows place of residence, which has been classified as either rural or urban depending on the level of social amenities and infrastructure available has received little attention in the literature. This study intends to address this gap in knowledge. Hence, of the six Awori communities studied in this work, four (4) are classified as rural while the remaining two (2) are urban. Hence, widows would be studied in these settings.

\subsection{Traditional Widowhood Rites}

The literature shows that many traditional rites are observed by bereaved spouses, both male and female in many societies (Afolayan, 2011 cited in Genyi and George-Genyi 2013). However, our focus in this article is on widows. Some of these rites are succinctly discussed below:

- Confinement: Oloruntimilehin (1991) has noted that confinement is a common feature of mourning practice for widows in southwest Nigeria. In observing this rite, the widow's movement is restricted for a specified period of a time, based on the society's culture. The conferment period ranges from two to three weeks for employed widows while for the unemployed widows it lasts for forty days. According to Afigbo (1989) the period for widowhood rites is four months, ten days in Islamic communities of SSA if the widow is pregnant the period is extended till her delivery. In non-Islamic settings, the period of mourning is longer and generally lasts for 12 months (Genyi and George-Genyi 2013). Thus the duration of this widowhood rite varies from one society to another. It also depends on the cause of death, the specific common beliefs of each group, the age and the number of children of the widow. Within this period widows are not allowed to fetch water, cook or go to the market like other women. They are normally assisted by their relatives.

- Defacement: This rite, according to Ojigho (1989) and Gender Across Borders (2009), involves scraping of widows hair in order to make them unattractive to the public. This practice usually makes them ugly and unattractive to the public. Probably to show that they are missing their dead husbands, since the hair is said to be the crowning glory of women.

- Disinheritance: This is another rite which hinges on denial of widow's right to inheritance in many societies. In Igbo and Yoruba traditions inheritance right is largely patrilineal and it involves only males (Nwogugu, 2000, cited in Umeh and Jane-Frances, 2015). Where there are no males, the inheritance right is passed to the brother of the late man. Although this is gradually changing in some cultures, many people still practice this in Igbo land.

Given the above scenario, the position of barren widows and those without male children could be terrible. In such cases, the in-laws usually take over the entire property without any consideration for the widow and her female children. In some cases, such widows are inherited by their husband brothers.

- Mourning Period: This rite has to do with widows' mourning over the death of their husbands. They are usually mandated by tradition to wear particular clothes, either black or white, depending on the culture. In certain cases, the widows are compelled to drink the water used in bathing the corpses of their deceased husbands. This usually occurs when they are suspected of having anything to do with the death of the husbands. In some traditional communities, widows are required to recite incantations in thick forests at night for the purpose of self "cleansing" (UN, 2001:8).

Variations in the observance of these widowhood rites by socio-demographic characteristics of widows is the area not yet covered in the literature. This study intends to fill this gap in knowledge.

\section{Methods}

\subsection{The Study Design}

This study adopts exposit study design because opinions of women who had observed widowhood rites in the selected six communities in Awori towns were sought for the study.

\subsection{Historical Background of Awori}

Ota is an ancient city in the Awori area of Ogun State. The city is the foremost Awori settlement (Kosebinu, 2000:1). Like most Yoruba towns and cities, Ota has its root traceable to Ife Ooye, the legendary cradle of the Yoruba people. Its 
emergence dates back to the early $14^{\text {th }}$ century. Ota town is the administrative and political headquarters of Ado-Odo/Ota Local Government Area, one of the 20 Local Government Areas in Ogun State. Incidentally, Ota is referred to as the natural capital of the Awori people of Nigeria. The town is strategically located with Lagos to the South, Idiroko to the West and Abeokuta to the North.

Ota district covers an area of approximately 190 square miles in the southwest corner of the Egba south administrative area in the former province of Abeokuta. About one-third of the area lies within a radius of twenty miles from Lagos. The Ota district is bounded on the Southeast by Agege and Alagbado areas of Lagos State to the southwest. There is a boundary with the Egbado (now Yewa) towns of llaro, Owode and the Awori village of Egan. Ota had an estimated population of 527,242, (261,523 males and 265, 719 females) in 2006 (National Population Commission, 2006).

\subsection{Population of Study and Sample Size}

The Awori constitute the study population in this research. The estimated population of Ota by 2010 was 612,068 . Of this figure, 303,598 were males and 308,469 were females. A sample of 912 was taken from the population.

\subsection{Sampling Technique}

Multi-stage sampling technique was used to select respondents from the study area. In this regard, Awori was divided into six communities. A proportional sampling was done to select respondents from these communities. Each of these communities was divided into streets and ten streets were randomly selected. Respondents were randomly selected from each household on these streets, depending on the number of persons in each building.

\subsection{Research Instrument}

A questionnaire containing both open and closed ended questions was used to collect information from respondents. The instrument was divided into two sections: A and B. Section A contained general questions on widows' socio-demographic characteristics while section B covered questions on widowhood rites and widows' observance of such traditional rites.

Because widows in the selected communities were identified for this study, the widows' were accessed by the assistance of the religious and traditional leaders of the various communities selected for the study. The widows were assembled at the Palace of their traditional rulers where the questionnaires were administered to them using face to face interview methods. The rationale was primarily because majority of the widows sampled had no form of schooling which posed a great challenge for them to fill the questionnaire all by themselves. The Research Assistants trained for the exercise assisted the non-literate widows

\subsection{Methods of Data Analysis}

Logistic regression was used in addition to cross-tabulations and simple percentages. This is because they are suitable for a study of this nature. The former was used to test the hypothesis formulated for the study while the later was used to describe data not related to the hypothesis.

\subsection{Study Hypothesis}

The major hypothesis for this study stated in the alternate form is as follows:

$\mathrm{H}_{1}$ : There is a significant relationship between the widow's socio-demographic characteristics (Age,meducation, income, occupation, number of children, sex of children, religion, type and form of marriage, place of residence) and widowhood rites performed/property inheritance.

\subsection{Analysis of Findings}

The SPSS was used to analyze the results for this study by engaging linear regression as the main statistical tool. This was to ascertain the extent of relationship that exists between widows' socio-demographic characteristics and observance of widowhood rites in the study area with a view to ascertaining the variable with the highest contribution or has the strongest effect on the observance of widowhood rites. 


\section{Results}

Table 1: Distribution of Widows by Demographic Characteristics

\begin{tabular}{|c|c|c|}
\hline Variable & Frequency & $\%$ \\
\hline 1. Research locations & \multirow[b]{2}{*}{110} & \multirow[b]{2}{*}{11.7} \\
\hline Agbara & & \\
\hline Atan & 161 & 17.1 \\
\hline Igbesa & 238 & 25.3 \\
\hline lju & 105 & 11.2 \\
\hline llogbo & 86 & 9.1 \\
\hline Ota & 242 & 25.7 \\
\hline Total & 942 & 100 \\
\hline 2. Whether respondent was Awori & \multirow[b]{2}{*}{881} & \multirow[b]{2}{*}{93.5} \\
\hline Yes & & \\
\hline No & 6 & .6 \\
\hline Partly & 55 & 5.8 \\
\hline Total & 942 & 100 \\
\hline 3. No of years lived in Awori & \multirow[b]{2}{*}{99} & \multirow[b]{2}{*}{10.5} \\
\hline $1-10$ & & \\
\hline $11-20$ & 123 & 13.1 \\
\hline $21-40$ & 214 & 22.7 \\
\hline $41-60$ & 314 & 33.3 \\
\hline $61+$ & 192 & 20.4 \\
\hline Total & 942 & 100 \\
\hline 4. Age of respondents & \multirow[b]{2}{*}{91} & \multirow[b]{2}{*}{9.7} \\
\hline 40 & & \\
\hline $40-44$ & 98 & 10.4 \\
\hline $45-49$ & 101 & 10.7 \\
\hline $50-54$ & 156 & 16.6 \\
\hline $55-59$ & 80 & 8.5 \\
\hline $60-64$ & 162 & 17.3 \\
\hline $65-69$ & 83 & 8.7 \\
\hline $70+$ & 171 & 17.8 \\
\hline Total & 942 & 100 \\
\hline Mean & 55.7 & \multirow[b]{3}{*}{29.0} \\
\hline 5. Number of Children & & \\
\hline |less than 4 & 273 & \\
\hline $4-5$ & 383 & 40 \\
\hline $6+$ & 286 & 30.4 \\
\hline Total & 942 & 100 \\
\hline Mean & 4.49 & \\
\hline 6. No. of Male children & \multirow[b]{2}{*}{581} & \multirow[b]{2}{*}{61.6} \\
\hline Less than 3 & & \\
\hline 3 and above & 361 & 38.3 \\
\hline Total & 942 & 100 \\
\hline Mean & 2.23 & \\
\hline 7. No. of Female children & \multirow[b]{2}{*}{561} & \multirow[b]{2}{*}{59.6} \\
\hline Less than 3 & & \\
\hline 3 and above & 381 & 40.6 \\
\hline Total & 942 & 100 \\
\hline Mean & 2.30 & \\
\hline
\end{tabular}

Source: Researchers' Field Survey (2016)

Table 1 shows the distribution of widows by their demographic characteristic. These involve research location, place of origin, number of years lived in Awori community, age of respondents, number of children, number of male and female children, and sex of children preferred.

Out of the six communities studied, Ota had the highest number of respondents with $25.7 \%$ of the sampled population. This was closely followed by Igbesa, a rural community with $25.3 \%$ while llogbo, another rural settlement in the area of study had the least number of respondents with $9.1 \%$. 
In respect of origin, $94 \%$ of respondents were descendants of Awori while the few who are non Awori may have been inadvertently included by the interviewers in the course of data collection. Therefore, it could be concluded that the findings in this study safely represents findings among the Awori people.

From panel 3, of Table 1, 11\% had lived in Awori between one and 10 years, 13\% had lived between 11 and 20 years while less than a quarter had lived in Awori for 21 years. In other words, most of the respondents had lived in Awori for between 41 and 60 years. Those who had lived for 61 years and above were about $20 \%$ of the total sample.

As indicated in Table 1, panel 4,17.8\% of the widows sampled in this study were within the age bracket of 70 years and above. Those below 40 years represent less than $10 \%$ of sampled population. A closer look at the same table shows that widows of different age brackets are found in the sample. The median age of the respondents was 54.5 years and the modal age was 55.0 years

From Table 1, panel 5, a large number of the widows had between 4 and 5 children which represents $40 \%$ of the total population. This is closely followed by respondents with 6 children and above, representing $30 \%$. Widows with less than 4 children represent less than $30 \%$. The average number of male and female children ever born by the sampled population is 4.5 . Virtually all the respondents had at least one child. The maximum number of children by the respondents sampled is 11 .

Table 1, panel 6 reveals that, over $60 \%$ of the widows had less than 3 male children. The remaining less than $40 \%$ had 3 male children and above. The average number of male children from the distribution is 2.2 with the highest number of male children put at8. Although majority of the respondents had below 3 male children, there are others with as many as 8 male children

Finally from Table 1, panel 7, 561 respondents representing 60\% of the total sample had between 1 and 2 female children, while the remaining $40 \%$ had 3 female children and above. The average number of female children by the respondents is 2.3 which is slightly higher than the figure for male children. In spite of this difference, the maximum number of female children by the sampled population is also 8 . Over $2 / 3$ of the respondents preferred both male and female children. To majority of the respondents, children are of high premium irrespective of sex. According to them, what a male child can do, a female child can also do. Thus, it is immaterial whether the children produced from a given marital union are male or female. However, about $21 \%$ of the respondents prefer male children while only about $8 \%$ prefer female children.

\section{Testing of Hypothesis}

$\mathrm{H}_{1}$ : There is a significant relationship between the widow's socio-demographic characteristics (Age, education, income, occupation, number of children, sex of children, religion, type and form of marriage, place of residence) and widowhood rites performed/property inheritance.

Table 2 shows the coefficient of widow's personal attributes and widowhood rites in the target population where:

Age means the actual age of widow which can be categorized as either young, middle-age or aged widows depending on the bracket;

Education is categorized as follows: no schooling, primary, secondary and tertiary.

Occupation implies what the widow does for a living. In what sector of the economy does she earn her living?

Income means the total earnings of the widow from her occupation or other sources within a specified period of time. The theoretical assumption is that there is higher independence and possibility for higher control on the widowhood circumstances for widows with higher income

Type of marriage consummated by the widow implies traditional, Christian or Islamic marriage. It is assumed that the different ideologies assumed by each marriage type would likely influence widowhood rites and property inheritance

Table 2: Coefficient of Widows' Personal Attributes and Widowhood Rites

\begin{tabular}{|l|c|c|c|c|c|}
\hline \multirow{2}{*}{ Mode 1 } & \multicolumn{2}{|c|}{ Unstandardized Coefficients } & Standardized Coefficients & T & Sig \\
\cline { 2 - 6 } & B & Std. Error & Beta & B & Std. Error \\
\hline 1 (Constant) & .625 & .145 & & 4.307 & .000 \\
Age & $.17 \mathrm{E} .005$ & .002 & .002 & -.025 & .980 \\
Education & -.101 & .020 & -.169 & -5.074 & .000 \\
Occupation & .022 & .016 & .043 & 1.329 & .184 \\
Income & .013 & .028 & -.034 & -.479 & .632 \\
Type of marriage consummated & .049 & .015 & .106 & 3.285 & .001 \\
\hline
\end{tabular}

Dependent Variable: Widowhood Rites

Source: Researchers' Field Survey (2016) 
Table 2 shows that age of widow is negatively related to widowhood rites performed. Thus, the older a widow becomes, the less the tendency to perform/observe widowhood rites. One reason that better explains this result is the fact that, when persons are aging, they are susceptible to diseases and health challenges which may reduce the stamina to observe very rigorous widowhood rites. However, this relationship is not significant. The regression analysis also reveals that the education of widows is significantly and negatively related to widowhood rites ( $p$ value of 0.000 ). Also, the income of the widow is negatively related (even though not significant) related to widowhood rites. Irrespective of a widow's income, widowhood rites is accepted as the norm as evidenced in the high level of conformity among the studied population without any form of schooling. The findings negate the assertion that widows with high income may pay their way through to escape widowhood rites. In our sample, only $3 \%$ of the widows earn N50,000 and above monthly. It will be extremely difficult for most of the widows with small income to pay their way through in attempt to evade widowhood rites. Education and type of marriage are the only predictors that are significantly related to widowhood rites among the study population. Thus, the higher the level of formal education (the possession of tertiary education for example) the less the likelihood that such widows will observe widowhood rites. In the words of a 55 year old widow at llogbo: "In the past, widowhood practice was observed religiously. These days, widowhood is not fully observed by the young ones, especially those working in the formal sector" who are most likely to possess tertiary education.

Table 3: Coefficient of Widows' Personal Attributes and Property Inheritance

\begin{tabular}{|l|c|c|c|c|c|}
\hline \multirow{2}{*}{ Mode 1 } & \multicolumn{2}{|c|}{ Unstandardized Coefficients } & Standardized Coefficients & T & Sig \\
\cline { 2 - 6 } & B & Std. Error & Beta & B & Std. Error \\
\hline 1 (Constant) & .25 & .073 & - & .349 & .727 \\
Age & -.001 & .001 & -.068 & -.973 & .331 \\
Education & .029 & .011 & .090 & 2.689 & .007 \\
Occupation & .029 & .009 & .107 & 1.329 & .184 \\
Income & .013 & .028 & -.034 & 3.291 & .001 \\
Type of marriage consummated & .007 & .008 & .028 & .861 & .389 \\
\hline
\end{tabular}

Source: Researchers' Field Survey (2016)

Table 3 describes the relationship between widows' personal attributes and property inheritance in Aworiland with a view to determining the strength of relationships and their level of significance. Age of widow is negatively related to property inheritance but not significant. The higher the age of widows, the less the tendency for property inheritance. Both education and occupation of widows are positively related to property inheritance and significant at $p$ value of 0.007 and 0.001 respectively. From Table 3, it is clear that widows' education and occupation are both positively related to property inheritance and statistically significant. 
Table 4: Logistic Regression showing the relationship between the independent variables and the dependent variable (Observance of widowhood rites)

\begin{tabular}{|c|c|c|c|c|c|c|c|}
\hline Independent I & & $B$ & S.E. & Wald & Df & Sig. & $\operatorname{Exp}(\mathrm{B})$ \\
\hline Occupation & Civil Servant & (RC) & & & & & \\
\hline & Farming(1) & .490 & 297 & 2.722 & 1 & .099 & 1.632 \\
\hline & Trading(1) & .653 & 263 & 6.159 & 1 & .013 & 1.921 \\
\hline & Artisans(1) & .994 & 386 & 6.641 & 1 & 010 & 2.703 \\
\hline Education & Tertiary Education & (RC) & .505 & & & & \\
\hline & No. Education (1) & -2.346 & & 21.546 & 1 & .000 & .096 \\
\hline & Pry (1) & -2.282 & .514 & 19.685 & 1 & .000 & 102 \\
\hline & Secondary (1) & -1.724 & .531 & 10.545 & 1 & .001 & 178 \\
\hline Religion & Traditional. Rel. & $(\mathrm{RC})$ & & & & & \\
\hline & Christianity (1) & -158 & & & 1 & & \\
\hline & & & 315 & 251 & & 616 & .854 \\
\hline & Islam (1) & -.195 & .305 & 410 & 1 & .522 & 823 \\
\hline thrantage type & Traditional. Marriage & (RC) & & & & & \\
\hline & Christian (1) & .242 & 310 & .610 & 1 & .435 & 1.274 \\
\hline & Islamic (1) & .516 & .174 & 8.791 & 1 & .003 & 1.675 \\
\hline & Age (Years) & & 228 & & 5 & .825 & 11893527 \\
\hline & & & & 2.168 & & & \\
\hline & Age group (1) & 20.897 & 845.066 & .000 & 1 & .999 & .082 \\
\hline & Age group (2) & .298 & .329 & .824 & 1 & .364 & 1.347 \\
\hline & Age group (3) & .059 & .231 & .065 & 1 & .799 & 1.061 \\
\hline & Age group (4) & .172 & 189 & .827 & 1 & .363 & 1.188 \\
\hline & Age group (5) & .236 & 188 & 1.563 & 1 & 211 & 1.266 \\
\hline & Sex & & & .351 & 2 & .839 & \\
\hline & Male & .100 & .171 & .342 & 1 & .558 & 1.105 \\
\hline & Female & .000 & 253 & .000 & 1 & .999 & 1.000 \\
\hline & & .185 & .220 & .705 & 1 & .401 & 1.203 \\
\hline & Jointly(1) & & & & & & \\
\hline & Constant & 2.218 & 1.206 & 3.386 & 1 & .066 & 9.193 \\
\hline
\end{tabular}

a Variable(s) entered on step 1: Farming, Trading, Artisans, NO. Education, Pry, Secondary, Christianity, Islam, Age group, sex, Jointly.

\section{Source: Researchers' Field Survey (2016)}

\section{Discussion of Results}

From Table 4, the overall percentage i.e. the overall behaviour of the logistic Regression model is 55.4 percent while observed variables are $61 \%$ above average. The model summary which explains the strength of association between the dependent and the independent variable is equivalent to $\mathrm{R}^{2}$ in the regression model. The 6 percent or 8 percent implies other intervening variables influencing widowhood rites apart from the selected independent variables.

From Table 4, civil servant is taken as the reference category (RC). Artisan is significantly related to observance of widowhood rites and it represents $0.1 \%$. Widows engaged in farming as occupation will be 1.632 times more likely to observe widowhood rites than the civil servants (RC). The demands of being a civil servant coupled with the bureaucracy involved in obtaining official permission to be absent from work for $X, Y$ period to observe widowhood rites is usually very difficult unlike a farmer who is self employed and may decide to stay away from the farm for as long as possible to observe widowhood rite in honour of the late spouse may partly explain this result. Similarly, A widow engaged in trading will be twice more likely observe widowhood rites than the civil servants (RC). The result shows that both widows engaged in trading and Artisan are statistically significant at $P$ value of 0.013 , and 0.010 respectively.

All education categories are negatively related and very significant to the observance of widowhood rites. This is contrary to the expectation that those without education should be more prone to observing widowhood rites. It is assumed that widows without any form of schooling will less likely observe widowhood rites compared to those with 
tertiary education which represents the Reference Category (RC).

All the marriage type (Islam and Christian Marriage) are negatively related to observance of widowhood rites compared to traditional marriage which represents the reference category (RC).

On religious affiliation, both Christian and Islamic religions are negatively related in terms of observance of widowhood rites. However, a widow that is a Christian will be 1.274 times more likely to observe widowhood rites than those who practice traditional religion. A Moslem widow will be 1.675 time more likely to observe widowhood rites than the traditionalist.

All age categories are positively related to observance of widowhood rites. However, they are not statistically significant to observance of widowhood rites in the study area.

Table 5: Variables in the Equation

\begin{tabular}{|c|c|c|c|c|c|c|c|}
\hline & & $B$ & S.E. & Wald & $\mathrm{df}$ & Sig. & $\operatorname{Exp}(B)$ \\
\hline \multirow[t]{21}{*}{ Step 1(a) } & Farming (1) & .490 & .297 & 2.722 & 1 & .099 & 1.632 \\
\hline & Trading (1) & .653 & .263 & 6.159 & 1 & .013 & 1.921 \\
\hline & Artisans(1) & .994 & .386 & 6.641 & 1 & .010 & 2.703 \\
\hline & NO. Educ (1) & -2.346 & .505 & 21.546 & 1 & .000 & .096 \\
\hline & $\operatorname{Pry}(1)$ & -2.282 & .514 & 19.685 & 1 & .000 & .102 \\
\hline & Secondary (1) & -1.724 & .531 & 10.545 & 1 & .001 & .178 \\
\hline & Xtian (1) & -.158 & .315 & .251 & 1 & .616 & .854 \\
\hline & Islam (1) & -.195 & .305 & .410 & 1 & .522 & .823 \\
\hline & Christian (1) & .242 & .310 & .610 & 1 & .435 & 1.274 \\
\hline & Islamic (1) & .516 & .174 & 8.791 & 1 & .003 & 1.675 \\
\hline & Age group & & & 2.168 & 5 & .825 & 118935274 \\
\hline & Age group (1) & 20.897 & 22845.066 & .000 & 1 & .999 & 3.082 \\
\hline & Age group (2) & .298 & .329 & .824 & 1 & .364 & 1.347 \\
\hline & Age group (3) & .059 & .231 & .065 & 1 & .799 & 1.061 \\
\hline & Age group (4) & .172 & .189 & .827 & 1 & .363 & 1.188 \\
\hline & Age group (5) & .236 & .188 & 1.563 & 1 & .211 & 1.266 \\
\hline & Sex & & & .351 & 2 & .839 & \\
\hline & $\operatorname{Sex}(1)$ & .100 & .171 & .342 & 1 & .558 & 1.105 \\
\hline & Sex (2) & .000 & .253 & .000 & 1 & .999 & 1.000 \\
\hline & Jointly (1) & .185 & .220 & .705 & 1 & .401 & 1.203 \\
\hline & Constant & 2.218 & 1.206 & 3.386 & 1 & .066 & 9.193 \\
\hline
\end{tabular}

a Variable(s) entered on step 1: Farming, Trading, Artisans, NO Educ, Pry, Secondary, Christianity, Islam, Age group, sex preferred, Jointly.

\section{Source: Researchers' Field Survey (2016)}

In many parts of SSA especially in Nigeria, death can occur as a result of natural/explicable causes such as sickness, disease, accidents etc or unnatural/inexplicable causes by witchcraft, sorcery, magic etc. irrespective of the cause(s) death, it is not age specific as death could occur at any age. However, the cultural belief and explanation of death varies across most African societies. Irrespective of age among the Awori studied, observance of widowhood rite was by all widows as dictated by the Awori culture.

Babalola (1997) points out that, "many studies have documented that the amount of resources a woman controls determines her relative position in household decision making and her ability to resist manipulation and interference by members of her husband's (conjugal) family". In the case of widowhood, this study however found that among the Awori sampled the extent to which women can avoid prescribed rites is not dependent on the amount of resources (income) that she control or possesses but on her level of educational attainment. The study found that widows with tertiary education hardly observe stipulated widowhood rites when compared to their counterpart with little or no form of schooling. 


\section{Summary of Findings}

No relationships were found to exist between the dependent and independent variables in the first model except for education and type of marriage which were found to be significantly related to widowhood rites. In the second model widows' education and occupation were both positively related to property inheritance and statistically significant.

\section{Recommendations}

On the basis of the finding in this study, we make the following recommendations: Aged widows especially those with health challenge should be exempted from observing the traditional widowhood rites to avoid double calamity of burying the widow during the mourning of her husband. This is in addition to removal of all widowhood rites/practices that erode the dignity, self esteem and fundamental human rights of the widow. Among the common widowhood practices observed by the Aworis studied, confinement indoor was mostly detested by the widow because it makes them very bored and not to be in tune with events outside their environment. It is against this premise that this study recommends shorter mourning duration of about two weeks to maximum of one month. This we believe will assist widows who are civil servants to return to work within the shortest possible time to avoid loss of their job and sustenaship of their families especially these days of economic hardship that prevents supports for widows from other members of the family.

\section{Conclusion}

The paper investigated the socio-demographic characteristics of widows: (age, education, income, occupation, sex and number of children, religion, type and form of marriage, place of residence) and the relationship with observance of widowhood rites in the study location. It concludes that widowhood rites are cultural practices that are held in high esteem by the Awori local group. Usually, widowhood rites are regarded as the highest mark of respect and love expressed in honour of the dead. They are, therefore, considered as sacrosanct and their violation often attracts negative consequences such as death of the violator or ostracization by family members or the larger community (George, 2010). The common widowhood practices among the Awori local group include confinement indoor, sitting on a mat, observance of vigil, taking of special bath, wearing of dark clothes and accessories, use of separate utensils and items as well as disposal of items used.

\section{References}

Afigbo, A. E. (1989). "Widowhood Practices in Africa: A Preliminary Survey and Analysis", Proceedings of Better Life Programme for Rural Women Workshop on Widowhood Practices in Imo State, Owerri: Government Printer, June 6-7, p.12.

Ahonsi, B. (1997). "Society, Culture and the Status of Widows in Contemporary Nigeria: A Gender Analysis". In: Owasonoye, B. and Ahonsi, B., Widowhood in Nigeria: Issues, Problems and Prospect, Lagos: Fredrick Ebert Foundation and Human Development Initiatives.

Azogu U. G. I. (1991) 'Women and children-A disempowered group under customary Law' in Ajibola Bola, (ed) Towards a Restatement of Nigeria customary laws fed. Ministry of justice Series. P.131

Babalola, S. (2001). 'Discussion of Society', Culture and the Status of Widows in Contemporary Nigeria: A Gender Analysis' in Widowhood in Nigeria (eds.) B. Owasanye \& Ahonsi, B.A, Friedrich Eber Foundation and Human Development Initiatives Lagos P.51-53.

Bier William G. S.J. Ed.(1968). Women in modern life: the psychology series NO.5 New York. Fordham Univ. Press, P.4

Cambridge Dictionaries Online, (2015). Income. Available on http://dictionary.cambridge.org/dictionary/english/income. Accessed on October, 15.

Cohen, M. F. (2006). The Condition of Women in Developing and Developed Countries The Independent Review, (XI)2: $261-274$.

Douglas, D. (1988) "The Study of Religion" in The World's Religions, (ed.) by R. Pierce Bearer, (Hert, England: Lion Publishing, 1988), pp. 10-11.

Ezejiofor, O. A. 2011). Patriarchy, Marriage and the Rights of Widows in Nigeria. Nnamidi Azikiwe University Journal of Arts and Humanities 12(1): 139-157

Gender across Borders, (2009). Widowhood rites in Nigeria. Available on http://www.genderacrossborders.com/2009/06/25/widowhoodrites-in-nigeria/ Accessed on December 9, 2015.

Genyi, G. A and George-Genyi, M. E. (2013). Widowhood and Nigerian Womanhood: Another Context of Gendered Poverty in Nigeria. Research on Humanities and Social Sciences, 3(7); 68-73.

George, T. O. (2010). Widowhood and Property Inheritance among the Awori of Ogun State, Nigeria" Unpublished PhD Thesis Department of Sociology, Covenant University, Ota, Nigeria 
George, T. O. and Amusan, T. A. (2012). "Religion and Acts of Worship amongst Nigerian People: Implications for Development and National Unity" in Peoples and Cultures of Nigeria Edited by A.S.Jegede, O.A. Olutayo, O.O.Omololu. \& B.E. Owumi Edited, Department of Sociology, University of Ibadan, Nigeri.

Goodridge, D., Lawson., Rennie D and Marciniuk, D. (2010). Rural Remote Health. 2010 Apr-Jun; 10(2):1349.

Holden, K. C. A and Kim, M 2002. Widowhood: Economic Issues. Available on www.encyclopedia .com/topic/widowhood.aspx.

Korieh, C. J. (1996). Widowhood Among the Igbo of Eastern Nigeria. Thesis submitted for the Degree of Master of Philosophy in History. University of Bergen, Norway.

Kosebinu, D. (2000). Alani Oyede: The People's Monarch Ota Bisrak Communications Ota, Ogun State. Population and Housing Census of the Federal Republic of Nigeria for 2006. National Population Commission published in 2009.

Kristof N and Wudunnaug. S. (2009). The Women's Crusade. The New York Times Magazine. Available on http://www.nytimes.com/2009/08/23/magazine/23Women-t.html?pagewanted=all\& r $r=0$

Lahana, E., Pappa, E and Niakas, D. (2011). Do place of residence and ethnicity affect health services utilization? evidence from Greece. Int J Equity Health, 10(16). doi: 10.1186/1475-9276-10-16

Lee, G. R., Demaris A., Bavin S., Sullivan R. (2001). Gender Differences in the Depressive Effect of Widowhood in Later Life. Journal of Gerontology: Social Sciences, 56B: 556-561.

Li L., Liang J., Toler A and Shengzu, G. (2005). Widowhood and depressive symptoms among older Chinese: Do gender and source of support make a difference? Social Science and Medicine, 60(3):637-647.

National Population Commission, (2006). A list of tables from analysis of the 2006 Census are available for download by clicking on titles of interest. Available on http://www.population.gov.ng/index.php/censuses. Accessed on Dec. 31, 2015.

Nwaogugu, A. C. (1989). "Widowhood Practices: Imo experience" Widowhood Practices in Imo State, p.39. 133(2): 143-160

Nwoga, D. I. (1989). "Widowhood Practices in Imo State" Paper presented at the Workshop on Widowhood Practices in Imo State. June 6-7.

Ojigho, O. 1989. Scrape her Head and Lay Her Bare - Widowhood Practices and Culture. Gender Across Borders on Facebook. Available on http://www.genderacrossborders.com/2011/10/28/scrape-her-head-and-lay-her-bare-widowhood-practices-andculture/

Oloruntimehin, O. (1991). Widowhood practices in Western Nigeria. An unpublished report, better life programme.

Omonijo, D. $O$ and Nnedum, O.O.U. (2012). A Study of E-Cheating Habits of Students in three selected Universities in Nigeria. Wufenia Multidisciplinary Journal; 19(9): 387-402.

Omonijo, D. O., Uche, O. O. C., Rotimi, O. A and K. L. Nwadialor. (2014). Social Analysis of Moral Malpractice Challenging Education Sector in Nigeria. British Journal of Education, Society \& Behavioural Science; 4(7): 965-986.

Oyekanmi, F.D. (2007). An Exploratory Study of the Impact of Widowhood on Children of Widows in Lagos, Published by the Human Development Initiatives (HDI), Lagos, Jan. 2007, p.2-7.

Pallares, I. (2011) "Place of Residence," The Oval: 4(1), Article 3. Available at: http://scholarworks.umt.edu/oval/vol4/iss1/3. Accessed on December 15, 2015

Walter, H. C. (1981). "Religion" in The World Book Encyclopedia Q-R, Volume 16. (Chicago: World Book - Chidcraft International, 1981), p.206.

Simon, R. (2002). Revisiting the relationships among gender, marital status and mental health. American Journal of Sociology, 107:1065-1096

Sociology Guide, (2015). Types of Marriages. Available on http://www.sociologyguide.com/marriage-family-kinship/Types-ofmarriages.php. Accessed on December, 15.

The Free Dictionary, (2015). Occupation. Available on http://www.thefreedictionary.com/occupation. Accessed on Dec. 15, 2015

Trivedi, J. K. M. D., Himanshu S. M. D and Mohan D. 2009), Psychological Aspects of Widowhood and Divorce, Mens Sana Monogr. Jan-Dec; 7(1): 37-49.

UN Division for the Advancement of Women (2000). Widowhood: invisible women, secluded or excluded. 2001. [Accessed 20 March, 2008]. Available at: http://www.un.org/womenwatch/daw/public/wom_Dec\%2001\%20single\%20pg.pdf

Umeh, A. S.and Jane-Frances, (2015). The influence of disinheritance of widows rights and their children s upbringing in Orsu local government of Imo State, Nigeria. International Journal of Current Research and Academic Review, 3(6): 305-315

United Nations (2001). Widowhood: Invisible women secluded or excluded. Available on http//www.un.org/womenatch/daw/public. Retrieved on May 24, 2012. 